\title{
The Effectiveness Test Of Wound Healing Daun Gatal (Laportea Decumana) Against Mice (Mus Musculus L)
}

\author{
Ratna Prabawati, Waskito Aji Suryo Putro, Yusnita La Goa, Lukman Hardia, Dyah Putri Utami \\ Universitas Pendidikan Muhammadiyah Sorong, Universitas Diponegoro \\ ratnaprabawati58@gmail.com,waskito_asp@ymail.com \\ yusnitalagoa81@gmail.com 1kman.hardia@gmail.com, dyah.utami@arjunawijaya.com
}

\begin{abstract}
Daun Gatal (Laportea spp) is one of the shrubs that are widely distributed in Papua from the coast to the mountains. Daun Gatal (Laportea spp) has been used for generations by the Papuan people as painkillers. Daun Gatal (Laportea spp) contains compounds monoxide, tryptophan, histidine, alkaloids, flavonoids, formic acid, and anthraquinones. This content is called "antacid" because it gives a sensation like being bitten by an ant. There are many itchy leaves in the village but often they are just left to dry, wither, die, and even be thrown away. The value of this leaf is very large if it is developed not only as an itchy leaf sheet but as a pharmaceutical product. (Simaremare, et al, 2019). This is supported by several research results stating that itchy leaf extract contains compounds of the alkaloid group, glycosides, steroids (Simaremare, 2014), also contains triterpenoid compounds and formic acid (Chrystomo, et al., 2016) and (Krisna and Santanina, 2019) which states that itchy leaves provide antibacterial activity. The type of research used is experimental research. The research design used was a randomized control group pretest and posttest design. The population in this study was white mice. The samples used in this study were white mice that had met the following inclusion and exclusion criteria. Inclusion criteria were female mice, bodyweight 20-30grams, age 2-4 months while the exclusion criteria. Included in the exclusion criteria in this study were mice that were sick or died in the study conditions. The results of the Extraction of Daun Gatal (Laportea Decumana), namely the itchy leaf sample that has been weighed at a concentration of $25 \%$ obtained from a mixture of itching leaf extract (25 grams) added with water $(30 \mathrm{ml})$ produces $18.5 \mathrm{ml}$. Itchy leaf extract at a concentration of $50 \%$ was obtained from a mixture of itchy leaf extract (50 grams) added with water $(30 \mathrm{ml})$ to produce $20.1 \mathrm{ml}$. Gatak leaf extract at a concentration of $75 \%$ was obtained from a mixture of itching leaf extract ( 75 grams) added with water $(30 \mathrm{ml})$ to produce $24.3 \mathrm{ml}$. The extraction method used is extracting the extract of itchy leaves. This method was chosen because the process is simple and does not involve heating so that it can prevent damage to chemical compounds that are not resistant to heating, especially flavonoids contained in itchy leaves. Based on the results of the data on the difference in wound diameter of mice, it showed that Treatment Group 1 with 25\% itching leaf extract and Treatment Group 2 with 50\% itching leaf extract almost had the same healing rate. Meanwhile, Treatment Group 3 with $75 \%$ itching leaf extract had the fastest healing rate among other concentrations. In contrast to Treatment Group 3, the control group had a much longer healing rate among other concentrations.
\end{abstract}

Keywords: Daun Gatal (Laportea spp), Extraction, Healing

\section{Introduction}

Human civilization has long used plants in its life. The use of plants as a medium for overcoming disease or maintaining health in the lives of Indonesian people is still ongoing. The types of plants used by each community group (ethnic/ethnic) are numerous and can be different in each group and this knowledge is still passed on to the next generation (Puro, 2012). Daun Gatal (Laportea spp.) is one of the shrubs that are widely distributed in Papua from the coast to the mountains. Daun Gatal (Laportea spp.) has been used for generations by the Papuan people as painkillers. Daun Gatal (Laportea spp.) contains compounds monoxide, tryptophan, histidine, alkaloids, flavonoids, formic acid, and anthraquinones. This content is called "antacid" because it gives a sensation like being bitten by an ant. There are many itchy leaves in the village but often they are just left to dry, wither, die, and even be thrown away. The value of this leaf is very large if it is developed not only as an itchy leaf sheet but as a pharmaceutical product. (Simaremare, et al, 2019). This is supported by several research results stating that itchy leaf extract contains compounds of the alkaloid group, glycosides, steroids (Simaremare, 2014), also contains triterpenoid compounds and formic acid (Chrystomo, et al., 2016) and (Krisna and Santanina, 2019) which states that itchy leaves provide antibacterial activity. Scattered itching leaves have been widely used by the people of India and the people of Papua as food and as medicinal ingredients, including for wound healing, reducing fever, and relieving pain (Lense, 2012). With the content and 
benefits of itchy leaves, it is necessary to research the effectiveness of itching leaves to see the effectiveness of itchy leaves, especially on wounds.

\subsection{Objectives}

The purpose of this study was to analyze the Effectiveness Test for Healing Itchy Leaf Wounds (Laportea Decumana) Against Mice (Mus Musculus L). Which will later be developed for healing to humans by providing bacterial activity

\section{Method}

The type of research used is experimental research. The research design used was a randomized control group pretest and posttest design.

\subsection{Ingredient}

The materials used in this study were equated and Daun gatal extract.

\subsection{Tools}

The tools used in this study were measuring cups, blenders, analytical scales, places to eat and drink for mice, gloves, wound making tools, namely razors and $1 \mathrm{cc}$ syringe.

\subsection{Population and Sample}

The population in this study was white mice. The samples used in this study were white mice that had met the following inclusion and exclusion criteria:

Inclusion criteria:

a. Female mice

b. 2030gram bodyweight

c. 2-4 months old

Exclusion criteria are the exclusion criteria in this study were mice that were sick or died in the research conditions.

\subsection{Daun Gatal Extract}

a. Wash the itchy leaves using clean running water, then drain

b. Weigh the itchy leaves using analytical scales

c. Smoothing the itchy leaves in a manual way that is by using mortal. After the leaves itch smoothly, then move the Daun gatal extract to the middle of the gauze.

\subsection{Well Prepare Sample Mencia (Mus Musculus)}

The sample used in this study was mice (Mus musculus) with a total of 28 tails that will be divided into 4 groups, each group consisting of 7 mice. Squeaking to be used each is done shaving on the right back, then making a wound incision with a length of $5 \mathrm{~cm}$. Each group is treated as follows:

a.In group 1 it was given treatment with a concentration of $25 \%$ daun gatal extract

b.In group 2 given treatment with concentrate $50 \%$ daun gatal extract

c.In group 3 was given treatment with a concentration of $75 \%$ daun gatal extract

d.In group 4 , control is given treatment by giving equates.

e. Each treatment is given until the wound heals.

f. Treatment of each concentration is given 2 times a day, namely morning at 9 and afternoon at $9 \mathrm{pm}$.

\subsection{Daun Gatal Extract Final}

a. Wash the itchy leaves using clean running water, then drain.

b. Weigh the itchy leaves using analytical scales.

c. Smoothing the itchy leaves in a manual way that is by using mortal. After the leaves itch smoothly, then move the daun gatal extract on the middle of the gauze.

d. Slashing squeak on the right back with a length of $5 \mathrm{~cm}$. Before the treatment, the hair around the back shaving with a razor blade, then aseptic action in the skin area that has been shaved with alcohol $70 \%$ then anesthesia on the 
back of the squeak using ketamine and xylazine with a ratio of 2:1 as much as $0.03 \mathrm{ml}$. Wounds are made on the back of the squeak that has been shaved by cutting it using a knife.

1) Treatment of Mencit

Mencit Squeak who has been injured on his back, then given a treatment of wounds according to his treatment group. Treatment of wounds on mice is done by giving itchy leaf extract given at every 09.00 and 21.00.

2) Measurement of Mencit

Diameter is done by measuring the diameter of the wound and the difference of the wound:

a) Diameter of wound Measurements of wound diameter was observed after administration of itchy leaf extract with $25 \%$ concentration, $50 \% .75 \%$, and control. Measurements are taken every day from day 1 to 7

b) The difference in Wound Diameter Observation of wound difference is done after the administration of itchy leaf extract $25 \%, 50 \%$, and $75 \%$ using itchy leaf extract. Data collection with the measurement of wounds on each treatment from day 1 to day 7 . After that, the calculation of the difference in the diameter of the wound closure with the formula

Dxselisih $=d x t 1-d x t 2$

Information

Dxselisih : difference in diameter of the wound $(\mathrm{mm})$

dxt1 : diameter of the wound on the 0th day

dxt10 : diameter of the 7 th day of the wound

\subsection{Analysis Data}

The data obtained was tested statistically with the SPSS 22 for the windows program using the Paired T-Test analysis method, a one-way ANOVA variance with a confidence level of $95 \%$.

\section{Results and Discussion}

Daun Gatal Extraction Results (Laportea Decumana) in samples of itchy leaves that have been weighed at a concentration of $25 \%$ obtained from a mixture of itchy leaf extract (25 grams) coupled with water ( $30 \mathrm{ml})$ produces $18.5 \mathrm{ml}$. Daun Gatal extract at 50\% concentration is obtained from a mixture of itchy leaf extract (50 grams) coupled with water $(30 \mathrm{ml})$ yielding $20.1 \mathrm{ml}$. Extract of data leaves at a concentration of $75 \%$ obtained from the mixture of itchy leaf extract $(75$ grams $)$ coupled with water $(30 \mathrm{ml})$ produces $24.3 \mathrm{ml}$. The extraction method is used with the removal of itchy leaf juice.

This method was chosen because the process is simple and does not involve heating to prevent damage to chemical compounds that are not resistant to heating, especially flavonoids contained in itchy leaves.

Average difference in diameter of squeak mencit

\begin{tabular}{|l|l|l|l|l|}
\hline NO & KP 1 & KP 2 & KP 3 & K \\
\hline 1 & 47 & 48 & 50 & 27 \\
\hline 2 & 48 & 49 & 50 & 29 \\
\hline 3 & 48 & 48 & 50 & 38 \\
\hline 4 & 48 & 48 & 50 & 30 \\
\hline 5 & 49 & 48 & 50 & 27 \\
\hline 6 & 49 & 50 & 50 & 29 \\
\hline 7 & 49 & 50 & 50 & 25 \\
\hline Mean & 48,28 & 48,71 & 50 & 29,28 \\
\hline
\end{tabular}

1) $\mathrm{K}=$ Control group (using equates)

2) $\mathrm{KP} 1=$ Treatment Group 1 (Itchy Leaf Extract 25\%)

3) $\mathrm{KP} 2=$ Treatment Group 2 (Itchy Leaf Extract 50\%)

4) $\mathrm{KP} 3=$ Treatment Group 3 (Itchy Leaf Extract 75\%) 
Based on the results of the difference in the diameter of the squeak wound showed that The Treatment Group 1 with daun gatal extract 25\% and The Treatment Group extract 2 with 50\% daun gatal extract almost had the same cure rate. While Treatment Group 3 with daun gatal extract $75 \%$ had the fastest healing rate among other concentrations. In contrast to Treatment Group 3, the control group actu longer the healing rate among other concentrations.

Paired Samples Statistics

\begin{tabular}{lll|l|l|l} 
& & Mean & $\mathrm{N}$ & Std. Deviation & Std. Error Mean \\
\hline Pair 1 & $\mathrm{K}$ & 29.29 & 7 & 4.192 & 1.584 \\
\cline { 2 - 6 } & $\mathrm{KP} 1$ & 48.29 & 7 & .756 & .286 \\
\hline \multirow{2}{*}{ Pair 2 } & $\mathrm{K}$ & 29.29 & 7 & 4.192 & 1.584 \\
\cline { 2 - 6 } & $\mathrm{KP} 2$ & 48.71 & 7 & .951 & .360 \\
\hline Pair 3 & $\mathrm{K}$ & 29.29 & 7 & 4.192 & 1.584 \\
& KP3 & 50.00 & 7 & .000 & .000 \\
\hline
\end{tabular}

Paired Samples Correlations

\begin{tabular}{lll|l|l} 
& & N & Correlation & Sig. \\
\hline Pair 1 & K \& KP1 & 7 & -.240 & .604 \\
\hline Pair 2 & K \& KP2 & 7 & -.394 & .382 \\
\hline Pair 3 & K \& KP3 & 7 &. &. \\
\hline
\end{tabular}

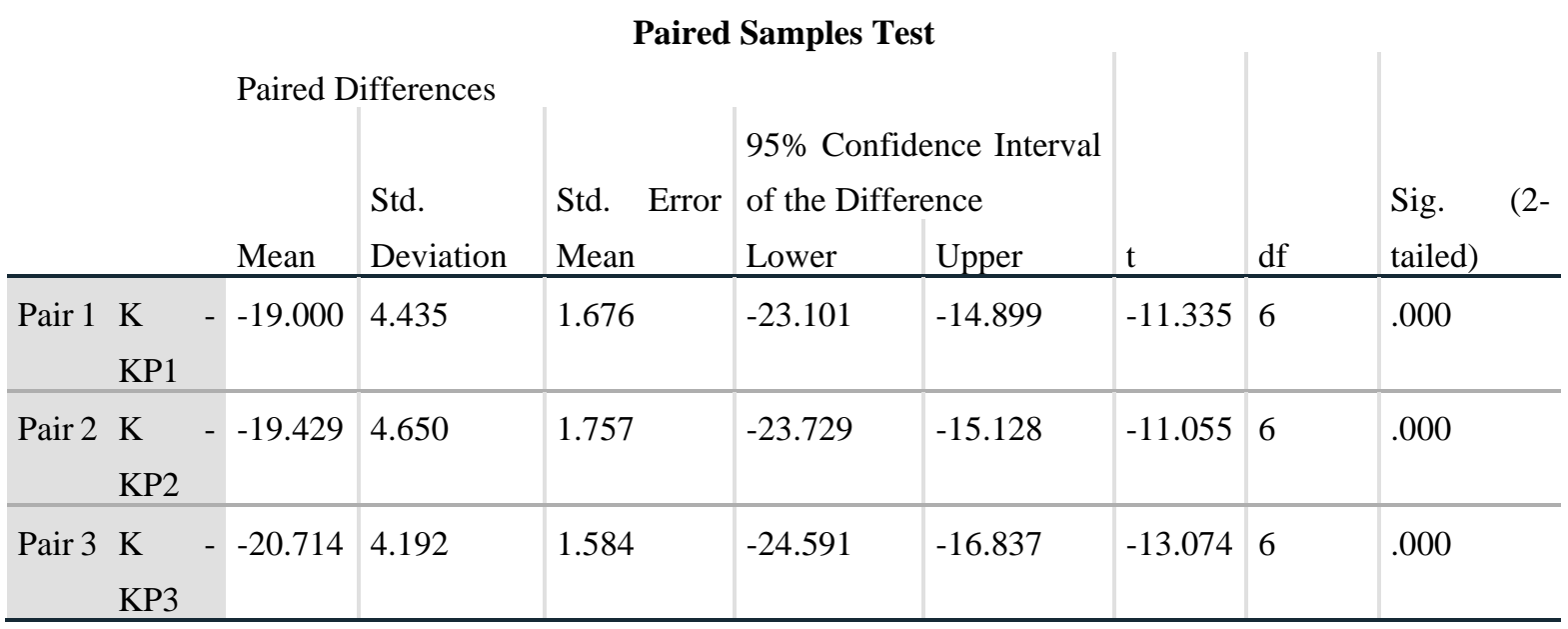

Information :

a. If the sig. (2-tailed) value is $0.000<0.05$, then $\mathrm{H} 0$ is rejected and $\mathrm{Ha}$ is accepted.

b. If the value $t$ calculates $>t$ table, then $\mathrm{HO}$ is rejected and $\mathrm{Ha}$ is accepted. Based on the table output of the "paired samples test" above, it is known that the negative value is $-11,335,-11,055$, and $-13,074$.

c. This negative value calculation is because the average value of the control group is lower than the average value of the experimental class. In the context of a case like this, the negative t count value can mean positive. So that the value of $t$ calculates to be $11,335,11,055$, and 13,074 . 
d. From the above output is known the value $\mathrm{df}=6$ and the value of $0.05 / 2$ equals 0.025 . This value will be used as a reference to determine the value of the $t$ table statistic. The $t$ table statistic is 2,447 .

e. Thus, since the value of $t$ calculates $11,335>t$ table 2,447 , the value $t$ calculates $11,055>t$ table 2,447 , the $\mathrm{t}$ count value is $13,074>\mathrm{t}$ table 2,447 . It can then be concluded that $\mathrm{H} 0$ was rejected and Ha was accepted.

\section{Distribusi Nilai tabel}

\begin{tabular}{|c|c|c|c|c|c|}
\hline \hline d.f & to 10 & to. & to.025 & to.01 & to.005 \\
\hline 1 & 3.078 & 6.314 & 12.71 & 31.82 & 63.66 \\
\hline 12 & 1.886 & 2.920 & 4.303 & 6.965 & 9.925 \\
\hline 3 & 1.638 & 2.353 & 3.182 & 4.541 & 5.841 \\
\hline 4 & 1.533 & 2.132 & 2.776 & 3.747 & 4.604 \\
\hline 5 & 1.476 & 2.015 & 2.571 & 3.365 & 4.032 \\
\hline 6 & 1.440 & 1.943 & 2.447 & 3.143 & 3.707 \\
\hline 7 & 1.415 & 1.895 & 2.365 & 2.998 & 3.499 \\
\hline 8 & 1.397 & 1.860 & 2.306 & 2.896 & 3.355 \\
\hline 9 & 1.383 & 1.833 & 2.262 & 2.821 & 3.250 \\
\hline 10 & 1.372 & 1.812 & 2.228 & 2.764 & 3.169 \\
\hline 11 & 1.363 & 1.796 & 2.201 & 2.718 & 3.106 \\
\hline 12 & 1.356 & 1.782 & 2.179 & 2.681 & 3.055 \\
\hline 13 & 1.350 & 1.771 & 2.160 & 2.650 & 3.012 \\
\hline 14 & 1.345 & 1.761 & 2.145 & 2.624 & 2.977 \\
\hline 15 & 1.341 & 1.753 & 2.131 & 2.602 & 2.947 \\
\hline 16 & 1.337 & 1.746 & 2.120 & 2.583 & 2.921 \\
\hline 17 & 1.333 & 1.740 & 2.110 & 2.567 & 2.898 \\
\hline 18 & 1.330 & 1.734 & 2.101 & 2.552 & 2.878 \\
\hline 19 & 1.328 & 1.729 & 2.093 & 2.539 & 2.861 \\
\hline 20 & 1.325 & 1.725 & 2.086 & 2.528 & 2.845 \\
\hline
\end{tabular}

\section{Conclusions}

Based on the results of the difference in the diameter of the squeak wound showed that The Treatment Group 1 with daun gatal extract 25\% and The Treatment Group extract 2 with 50\% daun gatal extract almost had the same cure rate. While Treatment Group 3 with daun gatal extract $75 \%$ had the fastest healing rate among other concentrations. In contrast to Treatment Group 3, the control group actu longer the healing rate among other concentrations.

\section{References}

Chrystomo LY, Karim AK, Antari NN, Dwa S, Wona Y, Pongtiku A. 2016. Traditional Papuan Obta plant. Center for the Development and Application of Traditional Medicine (SP3T), Papua Health Office. Nulisbuku Window of the World.

Krisna Kharisma Pertiwi \& Santanina Dian F. 2019. Antibacterial Activity of Itchy Leaves (Laporinterruptedupta L. Chew) against Staphylococcus an Escherichiaia coli. Scientific Journal: J-HESTECH, Vol. 2 No.1, 2019

Lenses, O. 20212. The Wild Plants Used as Traditional Medicines by Indigenous People of Manokwari, West Papua. Biodiversity, 98-106.

Puro I. 2012. Study of Antibacterial Activity of Itchy Leaves (Laportea Decumana (Roxb.) Wedd.) and Clove Benalu Leaves [Thesis]. Bogor: Faculty of Agricultural Technology, Bogor Agricultural Institute.

Simaremare, ES., Rani Dewi Pratiwi, Elsye Gunawan. 2019. Utilization of Itchy Leaf Plants in Arso XIV. Journal semar Vol.8 No.2, 2019. Thing. 10-16

Holle E, Simaremare ES, Yabansabra YY, Gunawan E, Ruban A. 2016. Physical Quality Test Formulation of Itchy Leaf Ointment (Laportea decumana (Roxb.) Wedd.). 


\section{Biographies}

Ratna Prabawati is a lecturer at Pendidikan Muhammadiyah University majoring in Biologi Education. He joined as a lecturer in 2017 until now. Her field of interest and research concentration is currently focused on issues biology education.

Waskito Aji Suryo Putro is a lecturer at Pendidikan Muhammadiyah University majoring in Sport Education. He joined as a lecturer in 2013. He studied undergraduate education and master's degree in Sport Education at Sebelas Maret University. Now he is a Relations manager at Pendidikan Muhammadiyah University until now. His field of interest and research concentration is currently focused on issues of sport science and natural science.

Yusnita La Goa is a lecturer at Pendidikan Muhammadiyah University majoring in Chemical Science. He joined as a lecturer in 2018 until now. Her field of interest and research concentration is currently focused on issues chemical.

Lukman Hardia is a lecturer at Pendidikan Muhammadiyah University majoring in Farmacy Science. He joined as a lecturer in 2019 until now.

Dyah Putri Utami is an expert at Kilang Pertamina International Refinery Unit VII Kasim majoring in Dispelledness and Fisheries Dipenegoro University. He joined as an expert in 2018 until now. Her field of interest and research concentration is currently focused on issues of Biodiversity. 